\title{
SEDIKIT GAMBARAN TENTANG ANALISA POLLEN \\ DALAM PENELITIAN ARKEOLOGI INDONESIA
}

Oleh: Sri Yuwantiningsih.

Perkembangan penelitian arkeologi ternyata tidak pernah lepas dari berbagai disiplin ilmu, yang kesemuanya bertujuan untuk mempercepat pemecahan masalah arkeologi yang ada. Penggunaan ilmu lain termasuk pengembangan teknik modern dalam arkeologi, meliputi juga konsep dari lingkungan ilmu-ilmu eksakta.

Keharusan menggunakan teknologi modern sebagaimana telah dicoba dan diuji kegunaannya di beberapa negara, tidak perlu diragukan lagi. Satu sebab pokok mengapa arkeologi amat membutuhkan bantuan teknologi modern ialah karena sifat data arkeologi yang tidak pernah lengkap, oaik dilihat dari segi jumlah maupun kemampuannya dalam menggambarkan kegiatan manusia dengan segala aspeknya. (Mundardjito, 1976: 193).

Analisa pollen merupakan salah satu kegiatan yang berhubungan dengan kegiatan multidisipliner dalam penelitian arkeologi. Kegiatan ini adalah usaha yang menyangkut penerapan ilmu dari lingkungan biologigeologi kearah arkeologi. Penerapan analisa pollen di negara-negara maju sudah lebih dahulu dikerjakan. Dengan pengembangan analisa pollen dalam penelitian arkeologi di Indonesia, akan membuat penelitian arkeologi setapak lebih maju dan diharapkan sesuai dengan negara maju yang lain.

Pada mulanya analisa pollen hanya dipakai dalam penelitian botani saja, tetapi kemudian analisa pollen ternyata dapat menunjang penelitianpenelitian lain termasuk penelitian arkeologi.

Dimbleby (1969 : 168) menyatakan tentang manfaat yang diperoleh dari analisa pollen dalam penelitian arkeologi antara lain: penentuan pertanggalan, pengungkapan kembali lingkungan lampau dan akan diketahui pula tentang apa yang dikerjakan manusia dalam lingkungannya tersebut.

Penentuan pertanggalan dengan analisa pollen merupakan penentuan pertanggalan relatip atau nisbi. Cara ini ialah dengan membandingkan flora yang terdapat di suatu tempat dengan flora yang sudah dikenal di tempat lain. Sedangkan pengungkapan flora lampau meliputi identifikasi dan komposisinya di alam. Dari data tersebut akan dapat digambarkan macam kegiatan manusia lampau dalam lingkungan tersebut.

Lingkungan kerja arkeologi yang meliputi masa munculnya manusia tertua sampai dengan masa Islam awal, maka tampaknya lingkup penelitian pollen terbagi menjadi 2 bagian, yaitu kala plestosen atau sebelumnya 
dan plestosen ini erat hubungannya dengan manusia purba, sedangkan pada kala holosen dimulai dari kehidupan gua sampai datangnya pengaruh Islam. Dalam lingkup penelitian untuk kala plestosen, ternyata analisa pollen sangat membantu dalam penentuan pertanggalan relatip.

Pada kala tersebut macam tumbuhan yang ada masih sangat terbatas, sehingga dapat dikatakan bahwa suatu macam tumbuhan dapat dipakai untuk menandakan waktu, yaitu kapan tumbuhan itu muncul, kapan dominan dan kapan musnah. Untuk kala berikut ternyata cara dating dengan pollen sudah jarang dikerjakan mengingat macam tumbuhan semakin banyak sehingga tidak dapat dibedakan mana yang lebih dahulu muncul. Seperti juga yang dikatakan oleh West (1968); Tite (1972 : 72) bahwa jangkauan analisa pollen untuk dating hanya meliputi kala plestosen dan post glasial saja. Lingkup penelitian pollen untuk kala holosen awal sampai sekarang, lebih mengarah untuk studi lingkungan. Pengetahuan tentang lingkungan lampau akan dapat membantu dalam penggambaran kembali keadaan sosial budaya manusia pada masa tersebut.

\section{Gambaran tentang Pollen}

Pollen merupakan serbuk sari dari suatu bunga, yang berfungsi dalam perkembang biakan generatif (secara kawin) dari tumbuhan tingkat tinggi. Dalam mempelajari pollen selalu diikut sertakan pula spora, yang merupaken alat perkembang biakan juga untuk 'elompok tumbuhan tingkat rendah antara lain luniut dan paku-pakuan.

Dalam pengelompokan jenis pollen, para ahli memakai dasar pembeda antara lain bentuk, ukuran, jumlah dan susunan appertura, juga ornamentasi dinding luar pollen. Bentuk pollen antara lain dapat bulat, lonjong atau tidak teratur. Ukurannya berkisar antara 5-200 mikron, tetapi ukuran rata-ratanya adalah 20 mikron. ( 1 mikron $=0,001 \mathrm{~mm}$ ). Appertura berupa lekukan yang biasanya terdapat pada dinding luar dari pollen. Di sini jumlah dan susunan appertura sangat bervariasi pada tiap jenis, tetapi ada pula pollen yang tidak dilengkapi dengan appertura tersebut. Untuk macam ornamentasi dinding luar pollen ada bermacammacam gambaran, seperti: jala, anyaman, berduri, bergelembung dan sebagainya (Erdtman, 1952:21).

Dinding pollen terdiri dari 2 lapis yaitu lapisan dalam yang lunak disebut intine dan lapisan luar yang keras disebut exine. Exine pollen tersusun atas senyawa kimia yang disebut sporopollenin. Ada keistimewaan dari sporopollenin ini yaitu, dalam keadaan anaerob (tanpa udara) akar tahan terhadap pengaruh fisik dan khemis dari lingkungannya, sebaliknya dalam keadaan aerob (ada udara) maka sporopollenin ini akan mudah terurai baik oleh enzim maupun oleh organi ma. (Brook and Shaw, 1968:232). Dari keterangan tersebut maka dimung inkan terjadinya pollen sebagai mikrofossil dalam lapisan-lapisan tanah. 


\section{Kegiatan analisa pollen.}

Kegiatan analisa pollen meliputi kegiatan di lapangan dan kegiatan di laboratorium. Kegiatan di lapangan merupakan kegiatan pengambilan sampel tanah, dari situs-situs yang dikehendaki dalam penelitian.

Sebelum dilakukan pengambilan, pertimbangan-pertimbangan dari para arkeolog perlu diperhatikan. Kegiatan di laboratorium meliputi kegiatan prosessing, pengamatan, penganalisaan dan pendokumentasian.

Dalam sampling maka jumlah sampel yang diambil seberat 200 gram, diambil dari lapisan-lapisan yang sesuai untuk tujuan pengamatan.

Untuk prosessing pollen dalam tanah ada beberapa metode, yang pada prinsipnya memäkai metode gabungan yaitu macerasi dan acetolysisis, (Kapp, 1969 : 12). Banyak pula metode lain yang dimodifikasi, disesuaikan dengan macam bahannya. Pengamatan dilakukan dengan mikroskop cahaya, menggunakan perbesaran $100-1000 \mathrm{kali}$, atau lebih baik lagi digunakan mikroskop elektron agar exine pollen dapat dilihat ornamentasinya secara jelas.

Penganalisaan meliputi perhitungan, idenifikasi lalu pembuatan tabel dan diagram. Menurut Faegri dan Iversen $(1975: 134)$ pollen tersebut dikelompokkan dalam:

AP (Arboreal Pollen) yaitu pollen jenis tumbuhan berkayu yang besar.

NAP (Non Arboreal Pollen) termasuk pollen jenis tumbuhan tidak berkayu yaitu jenis rumput-rumputan, semak dan herba.

AqP (Aquatic Pollen) termasuk pollen jenis tumbuhan yang hidup di air.

VP (Varia Pollen) termasuk bermacam-macam jenis yang belum dapat dibedakan dengan jelas satu sama lain.

Hasil analisa pollen diharapkan dapat memberikan data kepada penelitian arkeologi berupa lingkungan masa lampau dan penentuan pertanggalan untuk lingkup plestosen. Data lingkungan lampau terutama adalah gambaran jenis tumbuhan lampau. Data lingkungan lampau terutama adalah gambaran jenis tumbuhan lampau. Dari gambaran tumbuhan lampau akan diketahui pula keadaan iklim lampau, di sekitar kehidupan yang pernah berlangsung pada waktu itu. Pengaruh iklim terhadap tumbuhan dirasa sangat memegang peranan, terutama dalam distribusi maupun komposisi dari tumbuhan tersebut di alam. Dalam bidang penelitian arkeologi prasejarah, data lingkungan akan membantu pengungkapan jenis tumbuhan yang pernah mereka usahakan untuk makanan mereka, jenis bunga yang dipakai dalam upacara penguburan atau upacara lainnya. Penemuan periuk wadah bekal kubur megalith dan pada kubur-kubur lain sering ditemukan dalam keadaan kosong kecuali tanah; dengan analisa pollen diharapkan akan dapat membantu penafsiran tentang latar belakang sosial yang pernah ada masa itu. 
Dalam lingkup arkeologi klasik dan Islam, data tumbuhan juga akan membantu mengungkapkan kembali jenis tumbuhan lampau maupun jenis tanaman pertanian mereka. Penelitian pollen pada kompleks percandian atau kraton kuno, akan membantu menentukan macam tumbuhan yang sering terdapat pada lingkungan tersebut, sehingga akan dapat pula membantu dalam penentuan situs-situs baru.

Tentunya tidak semua tumbuhan dapat diungkapkan dengan analisa pollen, tetapi paling tidak sejumlah besar dari tumbuhan akan dapat mewakili dan menerangkan keadaan yang sebenarnya dari semua tumbuhan yang ada.

Gambaran-gambaran yang dapat diuraikan masih sangat terbatas, seperti halnya pandangan-pandangan tentang pollen dalam penelitian arkeologi yang masih dalam taraf perintisan untuk saat ini. Pembuktianpembuktian tentang analisa pollen akan diuji kebenarannya sehingga menjadi kenyataan yang dapat bermanfaat bagi penelitian arkeologi di Indonesia. Tentu saja untuk mencapai tujuan ini membutuhkan waktu, tenaga dan pikiran yang cukup banyak.

$* * * * *$

\section{Kepustakaan:}

Brooks, J and R. Shaw: "Chemical Structure of the Exine Pollen Walls 1968 and New Function for Carotenoids'. dalam Nature: 219. Macmillan (Journals) Ltd, Washington.

Dimbleby, G.W: 'Pollen Analysis'' dalam Science in Archaeology.

1969 Thames and Hudson.

Erdtman, G.: 'Pollen Morphology and Plant Taxonomý"

1952 The Cronica Botanica Co: Waltham, Mass, U.S.A.

Faegri, K and J. Iversen: "Textbook of Pollen Analysis" Hafner Press,

1975 a Division of Macmillan Publishing Co, Inc.

Kapp, R.O: 'Pollen and Spores"'

1969 M.C. Brown Company Publisher.

Mundardjito: 'Perkembangan Teknik Modern untuk Arkeologi Indonesia"

1976 dalam Seminar Arkeologi. Pusat Penelitian Purbakala dan Peninggalan Nasional, Jakarta.

Tite, M.S.: 'Methods of Physical Examination in Archaeology"'

1972 Seminar Press London and New York. William Cloves and Sons, Limited London, Beccles and Colchester. 


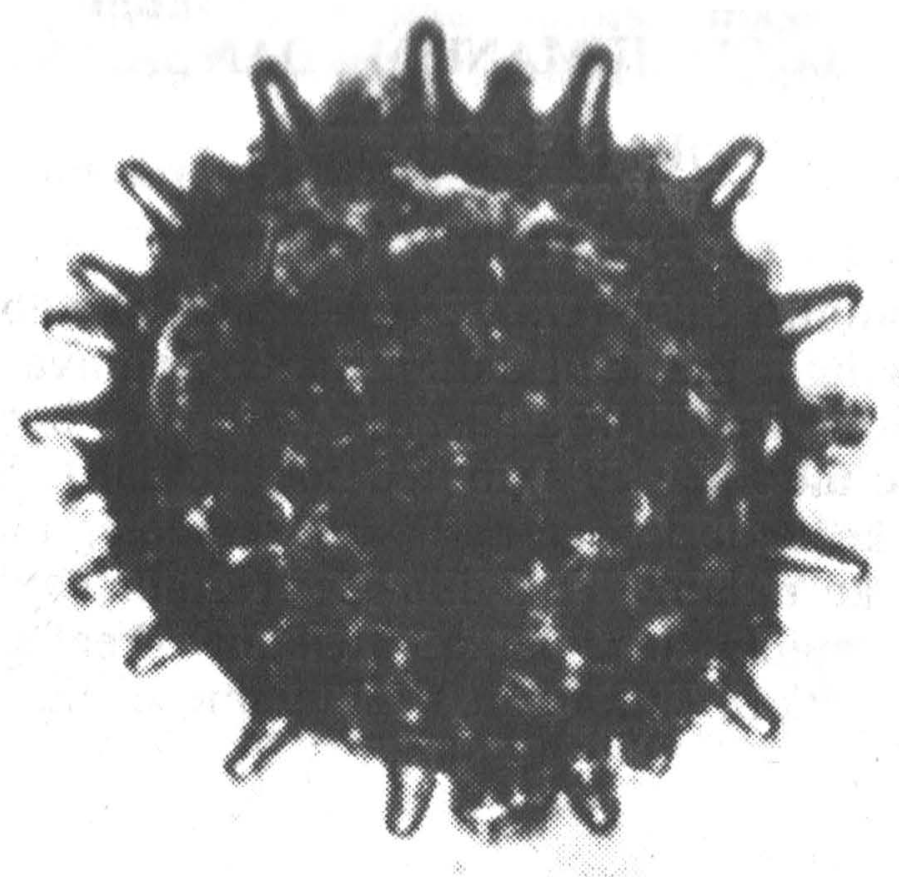

Pollen dari kembang sepatu (Hibiscus rosasinensis).

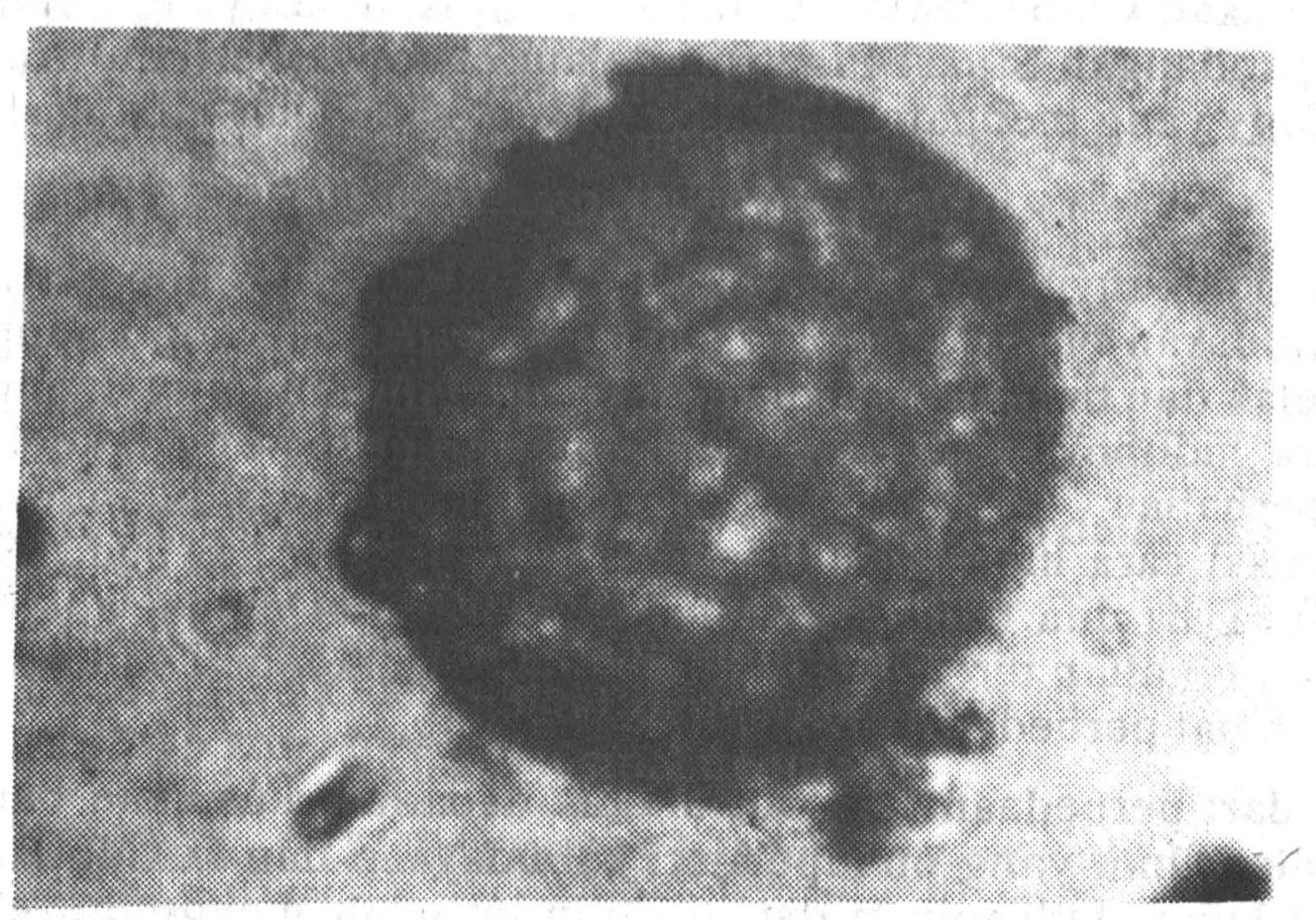

Pollen dari bunga rumput-rumputan (Cyperus sp.) 